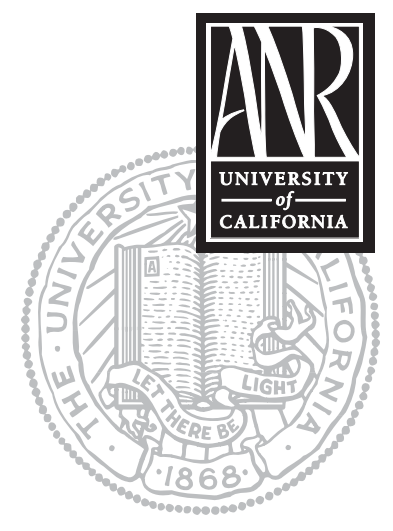

UNIVERSITY OF CALIFORNIA

Division of Agriculture and Natural Resources http://anrcatalog.ucdavis.edu

\title{
SMALL GRAIN PRODUCTION MANUAL
}

PART 1

\section{Importance of Small Grain Crops in California Agriculture}

LEE JACKSON, Extension Specialist, Small Grains, Department of Plant Sciences, University of California, Davis; BONNIE FERNANDEZ, Executive Director, California Wheat Commission; HERMAN MEISTER, University of California Cooperative Extension Farm Advisor, Imperial County; and MONICA SPILLER, Whole Grain Connection, Los Altos, CA

This publication, Importance of Small Grain Crops in California Agriculture, is the first in a fourteen-part series of University of California Cooperative Extension online publications that comprise the Small Grains Production Manual. The other parts cover specific aspects of small grain production practices in California:

- Part 2: Growth and Development, Publication 8165

- Part 3: Seedbed Preparation, Sowing, and Residue Management, Publication 8166

- Part 4: Fertilization, Publication 8167

- Part 5: Irrigation and Water Relations, Publication 8168

- Part 6: Pest Management-Diseases, Publication 8169

- Part 7: Pest Management-Insects, Publication 8170

- Part 8: Pest Management-Vertebrates, Publication 8171

- Part 9: Pest Management-Weeds, Publication 8172

- Part 10: Small Grain Forages, Publication 8173

- Part 11: Small Grain Cover Crops, Publication 8174

- Part 12: Small Grains in Crop Rotations, Publication 8175

- Part 13: Harvesting and Storage, Publication 8176

- Part 14: Troubleshooting Small Grain Production, Publication 8177

\section{SMALL GRAIN ACREAGE AND REGIONS OF PRODUCTION}

Production of small grain crops-wheat, barley, oat, triticale, and rye-has been a mainstay of California agriculture. From its meager beginning at Mission San Diego in 1769 , wheat grew to a million-acre-plus crop by 1980 . Overall, small grain acreage has declined since 1980, but it has fluctuated in recent years (USDA-NASS-CA 2005). From 1990 to 2003, planted wheat acres ranged from a low of 483,000 (195,000 ha) in 1991 to a high of 805,000 ( $326,000 \mathrm{ha}$ ) in 2003. Planted barley acres ranged from a low of 100,000 (41,000 ha) in 2003 to a high of 300,000 (122,000 ha) in 1990. Planted oat acres ranged from a low of 220,000 (89,000 ha) in 2000 to a high of 380,000 (154,000 ha) in 1990. Acreage of triticale is not reported officially, but over 50,000 acres $(20,000 \mathrm{ha})$ are grown in the state, primarily as a forage that is greenchopped or ensiled for dairies in the San Joaquin Valley. Triticale is also grown for grazing and haying in the Intermountain Region of north-central and northeastern California.

Small grains are grown throughout California. The state can be divided into five main production regions: the Intermountain Region of north-central and northeastern California; the Sacramento Valley (which includes the Sacramento-San Joaquin 


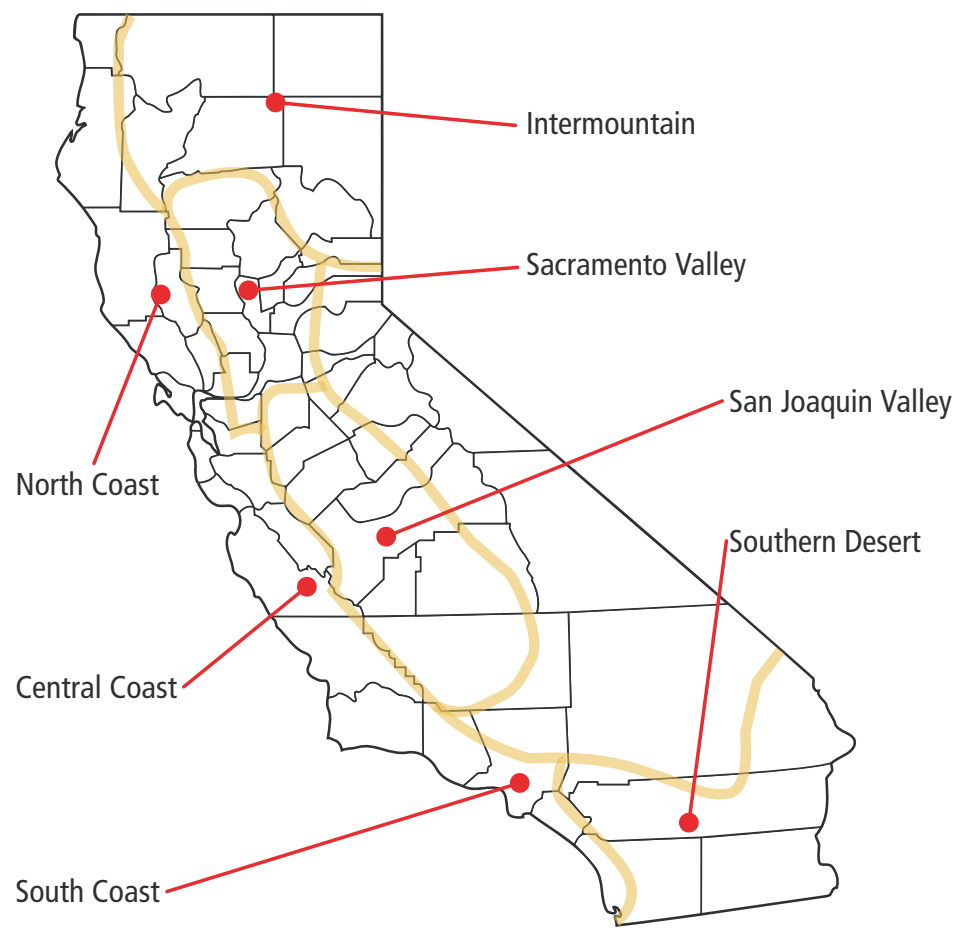

Figure 1. Primary production regions for small grains in California. Source: Strand 1990, p. 7.
Delta); the San Joaquin Valley; coastal areas (the North, Central, and South Coasts); and the Southern Desert (including irrigated southern desert areas) (fig. 1).

The Intermountain Region includes the Tulelake Basin, where small grains are grown primarily as spring-sown crops, usually in rotation with alfalfa, onion, and potato. Oat may be rotated with barley as a control for root-knot nematode. In the remainder of the Intermountain Region, small grains are primarily rotation crops for alfalfa. Spring-sown barley and fall-sown winter wheat (primarily soft white wheat) are most common. Oat, barley, and wheat are grown for grain or forage; triticale is grown for grazing and hay production. Some rye is planted for seed production, forage, or as a winter cover crop.

The Sacramento Valley produces a large share of California's fall-sown hard red wheat, along with fall-sown hard white wheat, barley, oat, and triticale. Conditions range from shallow soils along the western, eastern, and northern margins of the valley (rainfed grain production areas) to the deep, highly organic soils of the Sacramento-San Joaquin Delta. On the valley floor irrigated small grains are grown in rotation with alfalfa, cotton, corn, rice, safflower, sugarbeet, sunflower, melons, and a wide range of vegetable crops.

The San Joaquin Valley, like the Sacramento Valley, produces a large share of California's fall-sown hard red wheat as well as hard white and durum wheat, barley, oat, and triticale. Most of the production is irrigated and grown in rotation with other field and vegetable crops including tomato, cotton, alfalfa, and others. Rainfed grain production occurs primarily in foothill areas along the east side of the valley.

Coastal growing regions consist primarily of rainfed production systems. Conservation tillage is common in the central coastal region, where fall-sown spring barley is produced for feed. In areas of the central coast that produce high-value vegetable crops, rye grown as a green manure cover crop is an important rotation. In other locations, dry beans or alfalfa are rotated with small grains grown for grain or forage.

Valleys in the Southern Desert Region are major producers of durum wheat for the pasta market. All durum acreage is irrigated; some feed barley and forage oat are grown. Some rainfed small grain is produced under conservation tillage (reduced-tillage) in the northern portion of the area. Irrigated small grain crops are rotated with lettuce, melons, alfalfa, sugarbeet, cotton, and other crops.

\section{SMALL GRAIN PRODUCTION AND USE}

\section{Wheat}

Although most of California's wheat production is classified as fall-sown hard red spring wheat, other wheat classes (hard red winter, soft white winter, soft white spring, hard red spring, hard white, and durum) are also produced in California. Wheat is 
grown in more than 35 counties of the state. Among the characteristics of wheat cultivars that are important for California production are

- short stature

- lodging resistance

- tolerance to soil saturation

- disease resistance or tolerance

- shatter resistance

- responsiveness to nitrogen fertilizer

For most of the state, with the exception of some production in the Intermountain Region, cultivars currently available have a spring growth habit (do not require vernalization) and are day-length insensitive.

California wheat growers annually produce an average of about 1.1 million tons $(998,000 \mathrm{t})$ of common wheat (mostly fall-sown hard spring wheat but also lesser amounts of other wheat classes) and 250,000 tons (227,000 t) of Desert Durum wheat. A large proportion of California's hard red wheat is used for milling into bread flour or general purpose flour. Varying amounts are sold for feed, depending on price, supply, demand, and grain quality. California wheat is sold both in domestic and foreign markets.

Durum wheat is grown specifically for its semolina, a high-protein-content flour that is used to make macaroni, spaghetti, and other noodle products. Semolina produces a firm, translucent product that imparts a rich yellow color to noodles. The high-quality grain has protein content near or above 13 percent and is free of black point, a fungal disease that discolors the kernel and semolina. The incidence of this disease is influenced by the choice of durum cultivar and by cultural practices such as irrigation frequency and the amount and timing of nitrogen fertilization.

California annually exports up to 330,000 tons (300,000 t) of wheat. Destinations for California wheat have included Bangladesh, Bolivia, Ecuador, Indonesia, Italy, and Peru. China was the major importer of California wheat in the early 1980s, but due to quality and quarantine issues exports to China stopped and were only recently resumed on a limited scale. Hard red wheat is exported through California ports. Much of the exported wheat is produced and shipped by truck from within a 200-mile (320-km) radius of the Port of Sacramento or the Port of Stockton. Desert Durum wheat is exported "identity preserved" (i.e., not mixed with other durum wheat that does not have the Desert Durum trademark and quality traits associated with that designation) through U.S. Gulf ports, with California ports an option, depending on rail rates. The name "Desert Durum" is registered with the U.S. Patent Office and is owned by the California Wheat Commission and the Arizona Grains Research and Promotion Council.

California's domestic wheat flour milling capacity is the second-largest in the United States at 121,100 cwt (6,150 t) per day. Because California does not produce the quantities and diversity of quality characteristics needed within the state, wheat is brought in by rail from other states. Annually, California poultry and cattle producers buy 70 percent of their feed grain needs -7.3 million tons ( 6.6 million metric tons) - from outside California. Wheat partially fills this need, depending on the price of competitive grains.

\section{Barley}

Barley production in California consists primarily of fall-sown 6-row spring barley grown as a feed grain for livestock. Most of the acreage is concentrated in the Central Valley (Sacramento and San Joaquin Valleys) and surrounding foothills and in the south-central coastal area. Barley is grown as an irrigated rotation crop in the Central 
Valley and as a rainfed crop in the Central Valley foothills and south-central coastal foothills. A substantial acreage of 6-row or 2-row spring-sown barley is grown under irrigation in the Tulelake Basin in the northeastern portion of California, where it serves as a rotation crop for potato, onion, and alfalfa. Malting barley is occasionally grown in the Tulelake Basin and in the Central Valley. Hooded cultivars of barley are also grown for forage and are often a component of forage mixes.

About 50 percent of the barley crop produced in the United States and consumed domestically is used for animal feed, 45 percent is used for malt production, 3 percent as seed, and 2 percent in food products. California has about 240 brewers, who consume barley indirectly as malt.

Key characteristics for barley cultivars are disease resistance (to scald, stripe rust, leaf rust, net blotch, powdery mildew, and barley yellow dwarf virus), good tillering, short stature, and lodging resistance. Malt-quality cultivars must have high levels of bushel weight, kernel weight, malt extract, diastatic power, and alpha-amylase activity.

\section{Oat}

Oat is grown almost exclusively as a forage crop in California and is fed as hay, greenchop forage, or silage to cattle, sheep, and horses. Dairies use oat alone, in mixtures with other small grains, or in mixtures with vetch, winter peas, or other legumes to increase forage protein content. The pleasure horse market uses high-quality pure oat hay as a feed. Fine stems and leafiness are important for this market.

Oat is sometimes planted as a companion crop, or nurse crop, for alfalfa and can be seeded into old stands of alfalfa to increase forage yields in the last year of alfalfa production. Oat also is used as a cover crop.

A limited acreage of 25,000 to 30,000 acres (10,000 to 12,000 ha) of oat is grown for seed or as a feed grain for livestock. The grain can be fed to dairy cattle, horses, mules, replacement layers, and turkeys, as well as to hogs, beef cattle, and sheep. Oat grain is useful in dairy cattle and horse rations because of its high fiber and 12 to 15 percent whole grain protein, compared to 8 percent protein for corn and 10 percent for barley.

White-grained oat is processed into food products by the oat milling industry, but little, if any, California production is used for this purpose. Food products include oatmeal, oat flour, natural cereals, meat product extenders, cookies and breads, granolas, and baby food. Oat-based foods have unique value in human nutrition. Oat groats (the caryopsis, consisting of embryo, endosperm, and outer layers contained within the floral bracts, the lemma and palea) contain 16 percent or more protein. The lipid content of oat, a desirable source of energy, is about 1.8 times that of corn. Daily intake of oat and oat bran can aid in the lowering of blood cholesterol and in the control of diabetes. High-fiber diets including grains such as oat have been linked to decreased incidence of high blood pressure, heart attacks, and colon cancer.

\section{Triticale}

Triticale is grown throughout the wheat-growing areas of California. Its main use is forage for dairies in the Central Valley. In that capacity it is green-chopped at the boot or soft dough stage. Triticale also is grown in the Intermountain Region of northeastern California to complement perennial pastures by extending the grazing period (permitting grazing to continue later in fall and then to resume earlier in spring), and it is also grown for hay.

A limited triticale acreage produces grain for livestock feed or as a specialty food grain. Key characteristics for triticale include high grain and total biomass production, rapid spring growth for forage, lodging resistance, and disease resistance. 


\section{CHARACTERISTICS OF CALIFORNIA CULTIVARS}

Characteristics of cultivars of small grains grown in California can be found in the publication UC IPM Pest Management Guidelines: Small Grains, available at the UC Statewide Integrated Pest Management Program Web site, http://www.ipm.ucdavis.edu/PMG/ selectnewpest.small-grains.html.

\section{SMALL GRAIN BY-PRODUCTS}

Straw is a by-product of production of all the small grain crops. The harvested acreage of small grains in California annually generates approximately 1.5 million tons (1.36 million t) of straw, based on harvest indices (ratio of grain to total biomass) of 40 to 50 percent. Some growers bale the straw and incorporate the remaining stubble into the soil. Other growers spread the straw at harvest and incorporate the entire accumulation of crop residue. Incorporating stubble and straw helps reduce soil loss from wind erosion, increases rainfall infiltration, and reduces the rate of evaporation. Straw accumulation and incorporation over the long term can increase organic matter and soil biological activity. The disadvantages of incorporation are the time, effort, and expense involved and the length of time straw takes to decompose. Depending on location and weather, some growers burn the straw and stubble, provided it is permitted by state and local regulations and restrictions (air quality regulations may soon prohibit open-field burning). Burning has the advantage of disposing of crop residue almost instantly, allowing the next field operation to proceed immediately with little expense to the grower. Burning also may help reduce certain pathogen and weed populations.

Variable amounts of straw are used annually in California as bedding for racetracks, for roadside slope stabilization by the California Department of Transportation, and as the carbohydrate base for compost by mushroom farms. Straw also can serve as a biofuel for cogeneration plants. Small grain straw is grazed in many areas by cattle and sheep and provides a cheap source of roughage. Barley straw has been used to inhibit algae blooms in ponds.

Sizable markets for wheat straw exist in the packaging, building, and construction industries. Wheat straw can be made into straw-board paneling and is used in place of wood products, typically where particle board would be used. Straw board holds screws better than many wood-based materials and is lighter and cheaper to transport. Wheat straw can replace some of the petrochemicals and fillers used in the production of plastics. Wheat straw can also be used for straw-bale home construction: the walls offer excellent insulation at a rating of about $\mathrm{R} 48$.

\section{ORGANIC SMALL GRAIN PRODUCTION}

Demand exists in California for organically produced small grain crops for feed and food products and to meet the requirements of farm certification for growers adhering to organic guidelines. No single approach is used for growing organic small grains; farming systems, soil types, and fertility programs vary widely. "Organic" denotes products produced under the federal Organic Foods Production Act of 1990. The general guidelines for organic production are to use materials and practices that enhance the ecological balance of natural systems and that integrate the parts of the farming system into an ecological whole. Organic production is based on minimal use of off-farm inputs. Certified organic products are grown and processed under strict uniform standards, including inspections of fields and processing facilities, detailed record keeping, and periodic testing of soil and water to assure that organic production standards are met. Use of any synthetic substance is prohibited unless it is specifically allowed, while use of any nonsynthetic substance (natural material) is allowed unless it is specifically prohibited, under the national list of allowed and prohibited substances of the National Organic 
Program (see the Organic Farming Compliance Handbook Web site, http://www.sarep.ucdavis.edu/organic/complianceguide/). No prohibited materials can be applied to organic crops within 3 years of harvest for the production to be certified as organic.

An example of organic small grain production in California is organic wheat grown as a cash crop. Soft white wheat is the most commonly produced organic wheat, but hard and durum wheat classes are also grown. For successful production of organic wheat, the cultivars selected must be adapted to the area of production, have acceptable yield potential, show early (as well as season-long) vigor or be tall enough to compete effectively with weeds, and have adequate resistance to prevailing diseases and insect pests. The cultivars also need to have the desired end-use characteristics for the intended market. Organic whole grain products are an important niche for organic wheat.

Fertilization practices for organic small grain production include the use of cover crops, manures, compost, and crop rotation (e.g., including a legume crop appropriate for the region in the rotation scheme). Mineral amendments such as gypsum are occasionally added prior to planting.

Weeds are controlled by growing cover crops, sometimes by grazing or mowing, and by disking the weeds after the first fall rains and before planting. By sowing at a high rate and selecting cultivars with vigorous early-season growth, the small grain crop competes well with weeds and reduces their impact.

For successful organic production, segregation of organic specialty crops is essential, and it begins on the farm. An organic wheat grower expecting to sell a crop must be able to produce seed that has been thoroughly cleaned after it has been combine harvested, and must also be able to package and store it so that it is ready for milling without any further processing. Organic wheat growers are not permitted to use equipment, such as for tillage and harvesting, that has been used on nonorganic farms. The burden of owning equipment and providing storage facilities can be shared with other organic growers, for example, through grower cooperatives.

\section{REFERENCES}

American Oat Association. 1992. Strategic plan for U.S. oat research. American Oat Workers Conference Task Force Report.

Baker, B., S. L. Swezey, D. Granatstein, S. Guldan, and D. Chaney. 2004. Organic farming compliance handbook: A resource guide for Western Region agricultural professionals. Available online at the UC Sustainable Agriculture Research and Education Program Web site, http://www.sarep.ucdavis.edu/organic/complianceguide/.

California Wheat Web site, http://www.californiawheat.org/ca_wheat_summary.htm.

Clement, L. D, L. F. Jackson, T. E. Kearney, J. P. Orr, R. L. Sailsbery, and J. F. Williams. 1982. Wheat production in the Sacramento Valley. Oakland: University of California Division of Agricultural Sciences Leaflet 21323.

George, M. R., T. E. Kearney, and C. A. Schoner. 1982. Oat hay and silage production. Oakland: University of California Division of Agriculture and Natural Resources Leaflet 21265.

Hoffman, L. A., and J. Livezey. 1987. The U.S. oats industry. USDA Economic Research Service, Agricultural Economic Report 573.

Strand, L. 1990. Integrated pest management for small grains. Oakland: University of California Division of Agriculture and Natural Resources Publication 3333. 
UC IPM pest management guidelines: Small grains. 2003.

ANR Publication 3466. Available online at the UC IPM Web site, http://www.ipm.ucdavis.edu/PMG/selectnewpest.small-grains.html.

USDA National Agricultural Statistics Service, California Field Office (USDA-NASS-CA). 2005. California Agricultural Statistics Web site, http://www.nass.usda.gov/ca/bul/agstat/indexcas.htm.

\section{FOR MORE INFORMATION}

To order or obtain printed ANR publications and other products, visit the ANR

Communication Services online catalog at http://anrcatalog.ucdavis.edu. You can also

place orders by mail, phone, or FAX, or request a printed catalog of our products from:

University of California

Agriculture and Natural Resources

Communication Services

6701 San Pablo Avenue, 2nd Floor

Oakland, California 94608-1239

Telephone: (800) 994-8849 or (510) 642-2431

FAX: (510) 643-5470

E-mail inquiries: danrcs@ucdavis.edu

An electronic version of this publication is available on the ANR Communication Services Web site at http://anrcatalog.ucdavis.edu.

Publication 8164

ISBN-13: 978-1-60107-404-1

ISBN-10: 1-60107-404-2

(C) 2006 by the Regents of the University of California, Division of Agriculture and Natural Resources. All rights reserved.

The University of California prohibits discrimination or harassment of any person on the basis of race, color, national origin, religion, sex, gender identity, pregnancy (including childbirth, and medical conditions related to pregnancy or childbirth), physical or mental disability, medical condition (cancer-related or genetic characteristics), ancestry, marital status, age, sexual orientation, citizenship, or status as a covered veteran (covered veterans are special disabled veterans, recently separated veterans, Vietnam era veterans, or any other veterans who served on active duty during a war or in a campaign or expedition for which a campaign badge has been authorized) in any of its programs or activities. University policy is intended to be consistent with the provisions of applicable State and Federal laws.

To simplify information, trade names of products have been used. No endorsement of named or illustrated products is intended, nor is criticism implied of similar products that are not mentioned or illustrated.

Inquiries regarding the University's nondiscrimination policies may be directed to the Affirmative Action/Staff Personnel Services Director, University of California, Agriculture and Natural Resources, 300 Lakeside Drive, 6th Floor, Oakland, CA 94612-3550 (510) 987-0096. For a free catalog of other publications, call (800) 994-8849. For help downloading this publication, call (530) 297-4445.

This publication has been anonymously peer reviewed for technical accuracy by University of California scientists and other qualified professionals. This review process was managed by the ANR Associate Editor for Agronomy and Range Sciences.

pr-9/06-SB/CM 